\title{
A novel role for APOBEC3: Susceptibility to sexual transmission of murine acquired immunodeficiency virus (mAIDS) is aggravated in APOBEC3 deficient mice
}

\author{
Philip H Jones, Harshini V Mehta and Chioma M Okeoma*
}

\begin{abstract}
Background: APOBEC3 proteins are host factors that restrict infection by retroviruses like HIV, MMTV, and MLV and are variably expressed in hematopoietic and non-hematopoietic cells, such as macrophages, lymphocytes, dendritic, and epithelia cells. Previously, we showed that APOBEC3 expressed in mammary epithelia cells function to limit milk-borne transmission of the beta-retrovirus, mouse mammary tumor virus. In this present study, we used APOBEC3 knockout mice and their wild type counterpart to query the role of APOBEC3 in sexual transmission of LP-BM5 MLV - the etiological agent of murine AIDs (mAIDs).
\end{abstract}

Results: We show that mouse APOBEC3 is expressed in murine genital tract tissues and gametes and that genital tract tissue of APOBEC3-deficient mice are more susceptible to infection by LP-BM5 virus. APOBEC3 expressed in genital tract tissues most likely plays a role in decreasing virus transmission via the sexual route, since mice deficient in APOBEC3 gene have higher genitalia and seminal plasma virus load and sexually transmit the virus more efficiently to their partners compared to APOBEC3+ mice. Moreover, we show that female mice sexually infected with LP-BM5 virus transmit the virus to their off-spring in APOBEC3-dependent manner.

Conclusion: Our data indicate that genital tissue intrinsic APOBEC3 restricts genital tract infection and limits sexual transmission of LP-BM5 virus.

Keywords: APOBEC3, murine AIDS, LP-BM5 virus, MLV, o : female, O̊: male

\section{Background}

Viruses that use the genital mucosa as a portal of entry into the host include HPV, HSV, hepatitis B virus, and retroviruses like SIV, MLV, and HIV. Worldwide, HIV infection is pandemic in many countries and is primarily transmitted from infected persons to their sexual partners through contact with infected semen and vaginal secretions [1-4]. The control of sexual transmission is, therefore, pivotal to curbing the HIV pandemic, especially since the genital tract may also serve as a sanctuary in which HIV undergoes selective pressures [5-8] that may result to the emergence of drug-resistant HIV

\footnotetext{
* Correspondence: chioma-okeoma@uiowa.edu

Department of Microbiology, Carver College of Medicine, University of lowa, 51 Newton Road, lowa City, IA 52242-1109, USA
}

variants that may be sexually transmitted [9-11]. Indeed, it is known that patients with highly active antiretroviral therapy (HAART) - suppressed plasma viral load continue to shed viral RNA through the genital tract $[12,13]$. It is therefore critical to determine whether host factors can control virus replication and evolution within the male genital tract. Since we could not use human subjects for these experiments, a mouse model offers a practical alternative. Hence, we utilize the murine acquired immunodeficiency syndrome (mAIDs) model.

mAIDs is a mouse retroviral disease caused by the viral complex LP-BM5 [14]. LP-BM5 is a mixture of murine leukemia viruses comprised of the replication competent helper virus BM5e, the mink cell cytopathic focus-inducing virus, and the replication-defective virus 
BM5def, responsible for the immunodeficiency $[15,16]$. Infection of susceptible mice with LP-BM5 causes severe immunodeficiency syndrome similar to human AIDS $[14,17]$. Some of the similar characteristics between mAIDS and hAIDS include hypergammaglobulinemia, lymphadenopathy, severely depressed $\mathrm{T}$ - and B-cell responses to mitogens, increased susceptibility to infection, disease progression and the development of B-cell lymphomas and splenomegaly [18-22]. Despite the similarities between mAIDS and hAIDS, differences between the two infectious diseases exist. Unlike human AIDS, mice suffering from mAIDS develop mediastinal lymph node enlargement and may die of respiratory failure [23]. Propagation of mAIDS in mice requires the matrix (MA) and p12 of the Gag gene of BM5def [24]. Due to the similarity in virus transmission and disease outcome between LP-BM5- and HIV infections, mAIDs is a good model for examining sexual transmission of HIV and have been used for the initial evaluation of new drugs [25-29].

To be transmitted sexually, HIV and LP-BM5 will have to overcome host resistance in genital mucosal surfaces which are composed of different types and layers of epithelial cells and mucosa-associated lymphoid tissues (MALTs). The male and female genital mucosal layers are filled with cells of the immune system, including dendritic cells (DCs), macrophages and lymphocytes [30-36]. The immune cells in the genital mucosal surfaces express pattern recognition receptors (PRRs) such as Toll-like receptors, RIG-I-like receptors, and NODlike receptors [37-40] that function to recognize different pathogen associated molecular patterns (PAMPs) and stress signals leading to activation of the host innate and adaptive immune responses. Aside from innate and adaptive immune responses elicited by cells in the genital mucosal surfaces, the expression of anti-viral genes such as APOBEC3 (A3) in male reproductive organs has been reported $[41,42]$.

A3 proteins are virus restriction factors that encode DNA-editing enzymes. The human genome encodes 7 A3 genes (A3 - A, - B, - C, -D/E, - F, - G, - H), and the mouse genome encodes only 1 A3 gene [43]. A3 proteins are variably expressed in hematopoietic and nonhematopoietic cells, and in different tissues [42,44-47]. The most studied human A3 genes (A3G and A3F) and mouse A3 (mA3) are reported to confer intrinsic immunity to HIV-1 and other viruses including MMTV and MLV [45-52]. In the absence of HIV-1 viral infectivity factor (Vif), A3F and A3G are packaged into progeny virions via interactions with the nucleocapsid $(\mathrm{NC})$ protein and viral RNA. A3 proteins then inhibit infection in target cells by deaminating deoxycytidine residues on the DNA minus strand following reverse transcription and inducing mutations in newly synthesized HIV-1
DNA. In addition, A3F and A3G degrade reverse transcribed viral DNA prior to integration and induce mutation of viral genes in the integrated provirus [53-56]. However, in the presence of Vif, A3F and 3G are marked for proteasomal degradation [57-59], thus preventing their packaging into progeny virions; resulting in productive infection of target cells. Furthermore, there is growing evidence that A3 proteins can restrict HIV and other viral infection in a deamination independent manner $[45,46,60,61]$. We previously showed that endogenous $\mathrm{mA3}$ restricts MMTV infection in vivo in a deamination independent mechanism [45]. In addition to limiting virus replication, we recently demonstrated that the rate of milk-borne transmission of MMTV was significantly increased in mice harboring targeted mutation in the mA3 gene [47], demonstrating that A3 proteins play a role in containing milk-borne virus transmission.

In the present study, we define the role of A3 in sexual transmission of retroviruses using the mAIDs model and mice with targeted mutation in the mA3 gene. Our data indicate that mice with targeted mutation of APOBEC3 gene have a higher rate of sexual transmission compared to the wild type control, suggesting a role for APOBEC3 in limiting sexual transmission.

\section{Results}

$\mathrm{mA} 3$ is expressed in genital tract tissues and gametes

Healthy female and male C57BL/6 mice were euthanized, and different genital tract tissues and gametes were obtained for analysis of mA3 mRNA levels by realtime quantitative PCR (qPCR). We observed that mA3 is expressed at varying levels in male (Figure $1 \mathrm{~A}$ and $1 \mathrm{~B}$ ) and female (Figure 1C and 1D) genital tissues and gametes. In males, the epididymis and seminal glands have the highest level of mA3 expression, while the prostate gland, penis and spermatozoa have lower levels of $\mathrm{mA} 3$ expression (Figure 1B). The distribution of $\mathrm{mA} 3$ in female genital tissues shows that the cervix and mammary gland have the highest levels of expression while the oviduct, clitoral gland, uterine horn, and vagina express lower levels of mA3 mRNA (Figure 1D). Although both male and female reproductive organs express $\mathrm{mA} 3$ mRNA, male organs such as epididymis, seminal gland, testis, and vas deference make more mA3 transcripts than any female organ tested.

\section{mA3-deficient mice have increased susceptibility to acute LP-BM5 infection}

Since male genital organs and gametes express $\mathrm{mA3}$, and since we previously showed that $\mathrm{mA} 3$ deficient mice are more susceptible to MLV and MMTV [45,46,51,52], we hypothesize that mice lacking the mA3 gene (mA3-/-) will have higher virus load upon infection with LP-BM5 

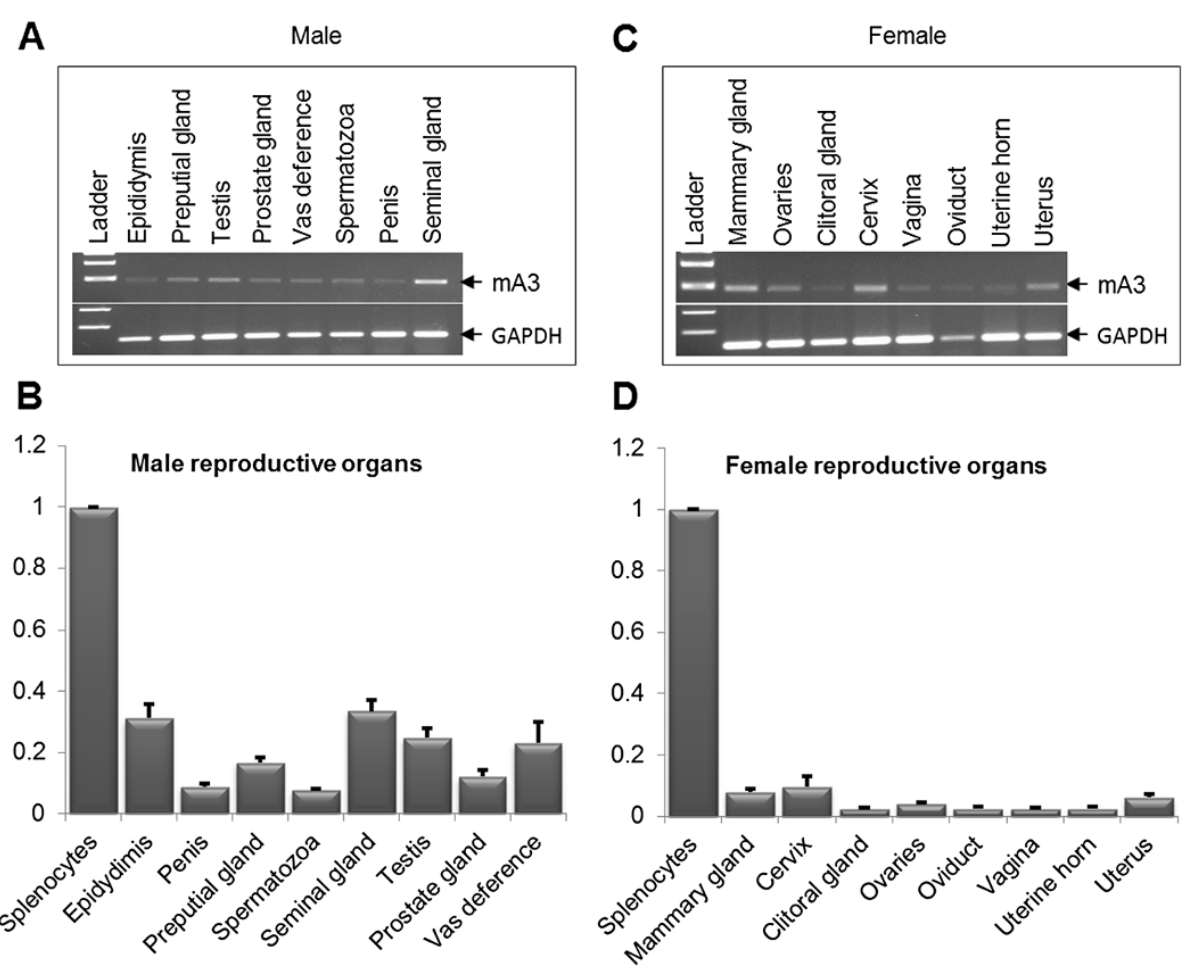

Figure $1 \mathrm{mA3}$ is expressed in murine female and male reproductive organs. Age-matched male and female WT mice on C57BL/6 background were sacrificed. At necropsy, tissue samples were obtained for RNA extraction. RNA was reverse transcribed and the resulting cDNA was used to examine levels of mA3 transcript by endpoint PCR (A and $\mathbf{C})$ and real-time quantitative PCR (B and $\mathbf{D})$. Data were normalized to GAPDH and presented as relative levels to splenic mA3 mRNA. Error bars are standard error; ${ }^{*}$ is significance with $p$ value equal or less than 0.05 ; and ${ }^{* *}$ is significance with $p$ value equal or less than 0.01 . Experiment was performed 3 times with similar results.

MLV. To test this hypothesis, we inoculated wild-type (WT) and mA3-/- mice with LP-BM5 virus subcutaneously (SubQ) on the footpad or intraperitoneally (IP). Footpad infected mice were sacrificed weekly for 4 weeks while IP infected mice were sacrificed at weeks 3 and 4 (Figure 2A). Spleen and testes (IP infected) or lymph nodes (SubQ infected) were used to examine the level of infection by qPCR. We detected significantly higher levels of LP-BM5 DNA in the lymph nodes of mA3-/- mice compared to the WT controls (Figure 2B). Lymph nodes were infected as early as 1 week post inoculation, and virus load increased in a time dependent manner. Examination of the spleen (Figure 2C) and testes (Figure 2D) for proviral DNA at 3 and 4 weeks after infection showed a significant and time dependent increase in virus load in $\mathrm{mA3}$ /- mice compared to the WT. We did not observe spleen or testes infection at weeks 1 and 2 following inoculation. To determine whether mA3 edits LP-BM5 genome, we generated and analyzed sequences of LPBM5 from total cellular DNA obtained from spleens and testes of infected male mice. Analysis of LP-BM5 sequence data showed no evidence of hypermutation (data not shown).
mA3 deficiency exacerbates mAIDs-associated lymphoproliferation and splenomegaly

Since C57BL/6 mice infected with LP-BM5 develop chronic splenomegaly, we predicted that loss of $\mathrm{mA} 3$ will result in severe splenomegaly. Age and weight matched WT, mA3+/-, and mA3-/- mice infected with LP-BM5 (Figure 3A) were examined for the development of splenomegaly. In general, gross appearance and size of the spleen were variable. mA3-/- mice show severe splenomegaly because their spleen sizes and weights were profoundly larger compared to the heterozygotes and WT controls in that order (Figure $3 \mathrm{~B}$ and $3 \mathrm{C}$ ). Although the spleens of infected mA3-/- mice were much larger than that of the WT, the WT spleen weights were significantly higher compared to the naïve mice (Figure $3 \mathrm{~B}$ and $3 \mathrm{C}$ ). Since most of the cells infected by LP-BM5 virus belong to the lymphocyte lineage $[62,63]$ and the infected $B$ and T cells greatly expand [62-65], we examined the percentage of $\mathrm{B} 220+$ and $\mathrm{CD} 4+$ expressing splenocytes using flow cytometry. LP-BM5 infection caused significant increase in B220 and CD4 expressing cells in mA3-dependent manner (Figure 3D to 3F). The percentage of B220 splenocytes were $25.8 \pm 0.1$; 

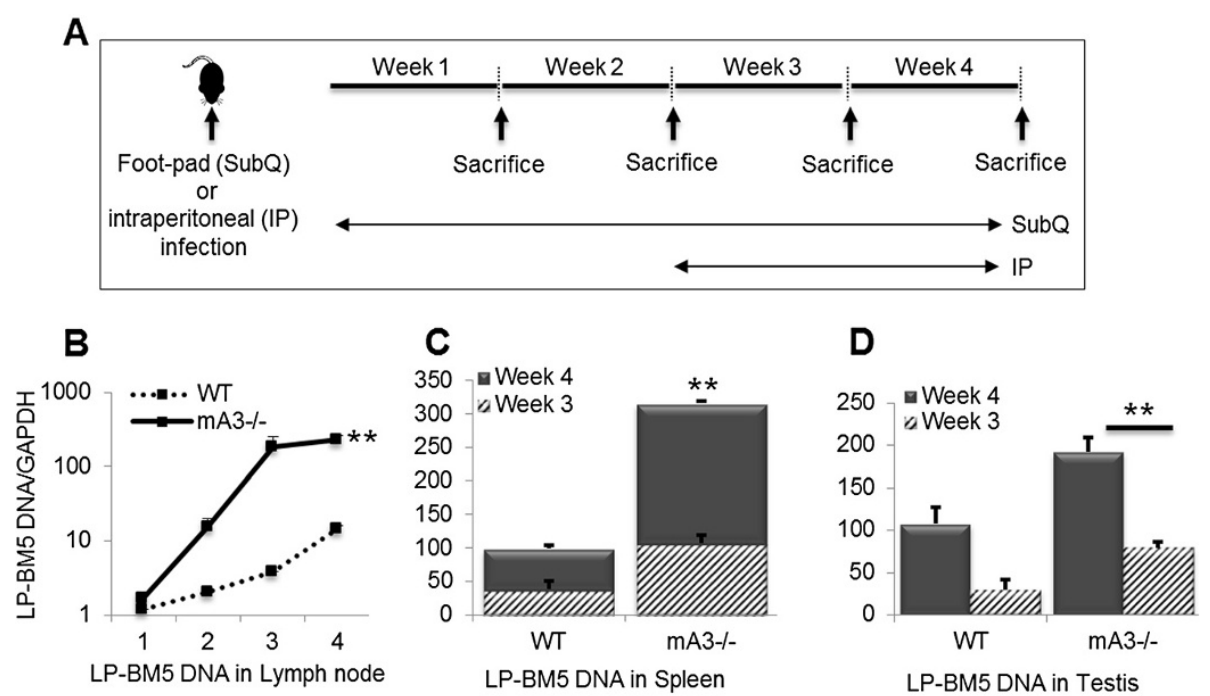

Time: Weeks post infection

Figure 2 Mice deficient in APOBEC3 gene are more susceptible to acute LP-BM5 virus infection. Age and weight-matched WT and mA3-/- mice on C57BL/6 background ( $n=5$ ) were inoculated with LP-BM5 virus subcutaneously (SubQ) on the right hind footpad or via intraperitoneal (IP) route (A). Mice were sacrificed at different time frames as shown on the figures. At necropsy, lymph nodes were collected from SubQ infected mice, while spleens and testes were obtained from IP infected mice. DNA was isolated from the different tissues and subjected to quantitative PCR (qPCR) to determine level of LP-BM5 infection in lymph nodes (B) spleen (C), or Testes (D). All qPCR data were normalized to GAPDH and presented as relative levels. Error bars are standard error; ${ }^{*}$ is significance with $p$ value equal or less than 0.05 ; and ** is significance with $p$ value equal or less than 0.01 . Experiments were repeated five different times with similar results.

$29.1 \pm 0.4 ; \quad 48.1 \pm 5.01 ; 57.0 \pm 3.22 ;$ and $79.5 \pm 6.34$ in naïve WT, naïve $\mathrm{mA} 3-/-, \mathrm{WT}, \mathrm{mA} 3+/-$, and $\mathrm{mA} 3-/-$ mice in that order (Figure $3 \mathrm{D})$. A similar observation was made upon examination of $\mathrm{CD} 4+\mathrm{T}$ cells. The percentage of CD $4+\mathrm{T}$ cells increased from $38.6 \pm 1.8$ in WT mice to $50.7 \pm 4.4$ in $\mathrm{mA3}-/$ - (Figure 3D). We also evaluated the expression of CD69 by B220+ B and CD4+ T cells after infection with LP-BM5. The percentage of B220+ cells expressing CD69 expanded from $4.77 \% / 4.29 \%$ in naïve $\mathrm{WT} / \mathrm{mA} 3-/$ - mice to $14.8 \%$, $17.6 \%$, and $22.2 \%$ in WT, $\mathrm{mA} 3+/-$, and $\mathrm{mA3}-/-$ infected mice in that order (Figure 3G). A similar observation was made on CD4+ T cells expressing CD69. The percentage of $\mathrm{CD} 4+\mathrm{T}$ cells expressing CD69 increased from $2.78 \% / 2.44 \%$ in naïve $\mathrm{WT} / \mathrm{mA3}-/$ - mice to $12.70 \%, 13.9 \%$, and $21.0 \%$ in infected $\mathrm{WT}, \mathrm{mA} 3+/-$, and $\mathrm{mA} 3-/-$ mice respectively (Figure $3 \mathrm{H}$ ). The expansion of CD69 expressing B220+ and CD4+ T cells has been previously reported in mice chronically infected with the LP-BM5 related retroviruses, Friend MLV [66] and MMTV [67].

\section{Mice lacking $\mathrm{mA} 3$ gene have higher genital infection and} seminal plasma virus load

The presence of HIV-1 virions in human seminal plasma and seminal vesicles has been demonstrated [68-72]. To examine the impact of $\mathrm{mA} 3$ on virus titre and the link to sexual transmission, we examined viral load in the testes, purified spermatozoa and seminal plasma obtained from the epididymis of WT, $\mathrm{mA} 3+/-$, and mA3-/- mice. Upon evaluation of sperm cells, no differences in cell morphology were observed prior to sperm purification (Figure 4A). We also did not observe any difference in the morphology of spermatozoa after purification (Figure 4B). However, sperm cells from mA3-/mice were significantly infected with LP-BM5 virus compared to the heterozygote and WT controls (Figure 4C). A similar observation was made in testicular DNA obtained from mA3-/- mice (Figure 4D). A comparison of viral RNA (vRNA) in cell-free seminal plasma as measured by qPCR showed high level of vRNA present in seminal plasma of mA3-/- (Figure 4E). To confirm that LP-BM5 MLV is present in genital tissues and seminal plasma, we used Western blot to detect viral capsid protein (p30) in these samples. The testicular cells and seminal plasma of mA3-/- mice have higher viral p30 protein (Figures 4F and 4G) compared to mA3+/- and WT counterparts. There appears to be a different banding pattern in mA3-/lane for $\alpha \mathrm{p} 30$. This banding pattern was seen with each experiment, but it is not clear why the difference and if the band is a doublet or a larger amount of the p30. Regardless, the high viral RNA and protein observed in mA3-/- mice indicate that these mice are more highly infected, and that their seminal plasma contains more 


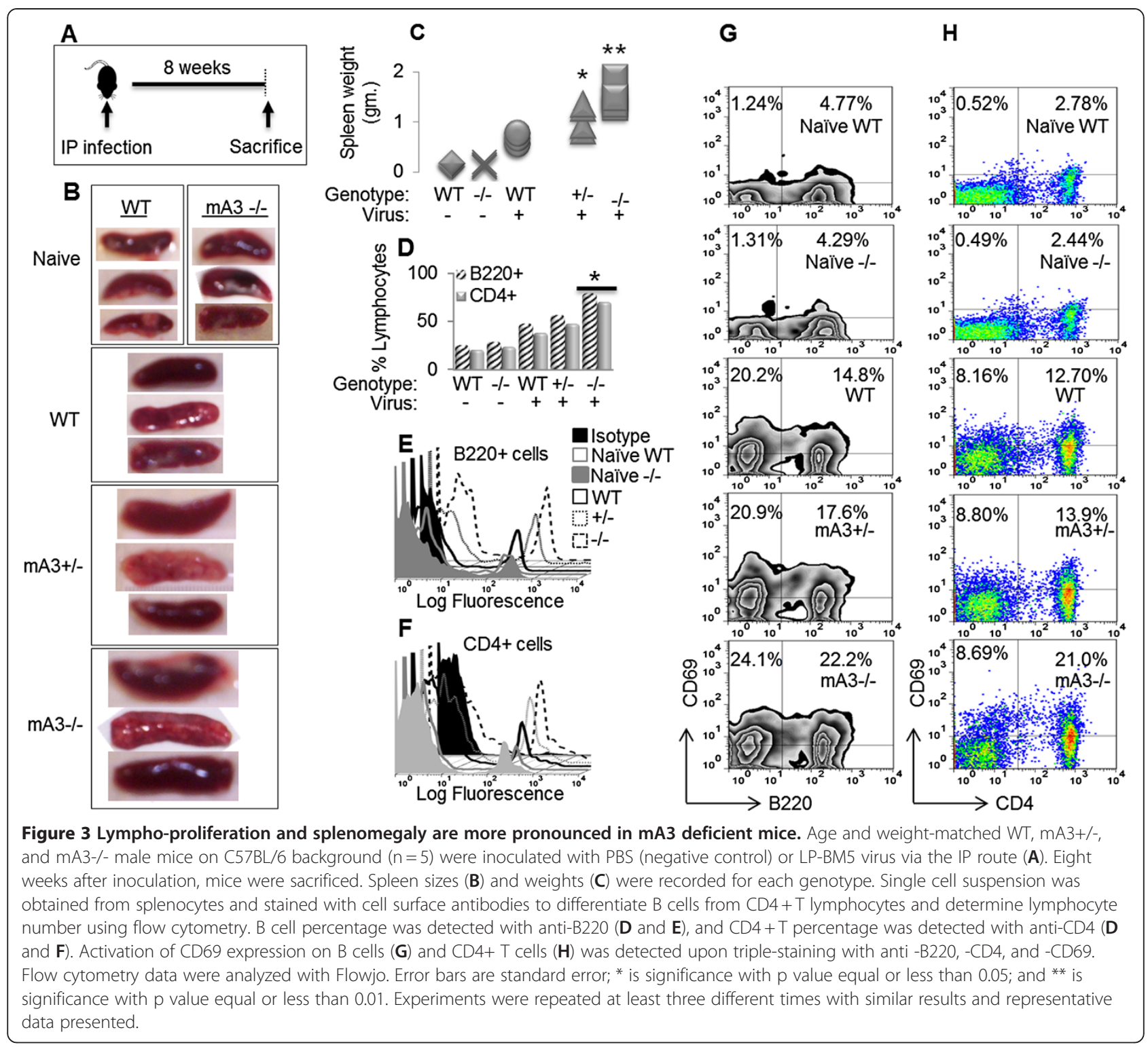

viruses. The empty GAPDH blot in figure $4 \mathrm{G}$ indicates that the virus prepared from the seminal plasma is devoid of cellular contamination. To determine whether high seminal plasma vRNA in mA3-/- mice reflects the infectiousness of virus in the semen, we infected WT splenocytes with a portion of purified cell-free seminal plasma virus for 24 hours. Seminal plasma virus from mA3-/was significantly more infectious than the $\mathrm{mA} 3+/$ - and WT controls because splenocytes that were infected with the mA3-/- virus have about 11 and 12 times more LPBM5 DNA than the mA3+/- and WT controls respectively (Figure $4 \mathrm{H}$ ). Examination of other genital organs also reveal that $\mathrm{mA3}-/$ - mice harbor significantly higher viral load (vRNA) compared to the $\mathrm{mA} 3+/$ - and WT controls (Figure 4I).

\section{Loss of APOBEC3 gene facilitates efficient sexual} transmission of LP-BM5

Previous studies have shown that murine genital organs are susceptible to LP-BM5 infection and that the virus is transmitted sexually [73]. To evaluate whether mA3 plays a role in sexual transmission of LP-BM5 from male to female mice, we infected age-matched male WT, mA3 +/-, and mA3-/- mice and mated infected mice with naïve females of different genotypes. Examination of testicular and splenic DNA reveals that all male mice were infected. However, higher levels of infection in the testes (Figure 5A) and spleen (Figure 5B) were observed in mA3-/- mice compared to their mA3+/- and WT counterparts. Furthermore, infected male mice transmitted the virus to their female partners of different genotypes 


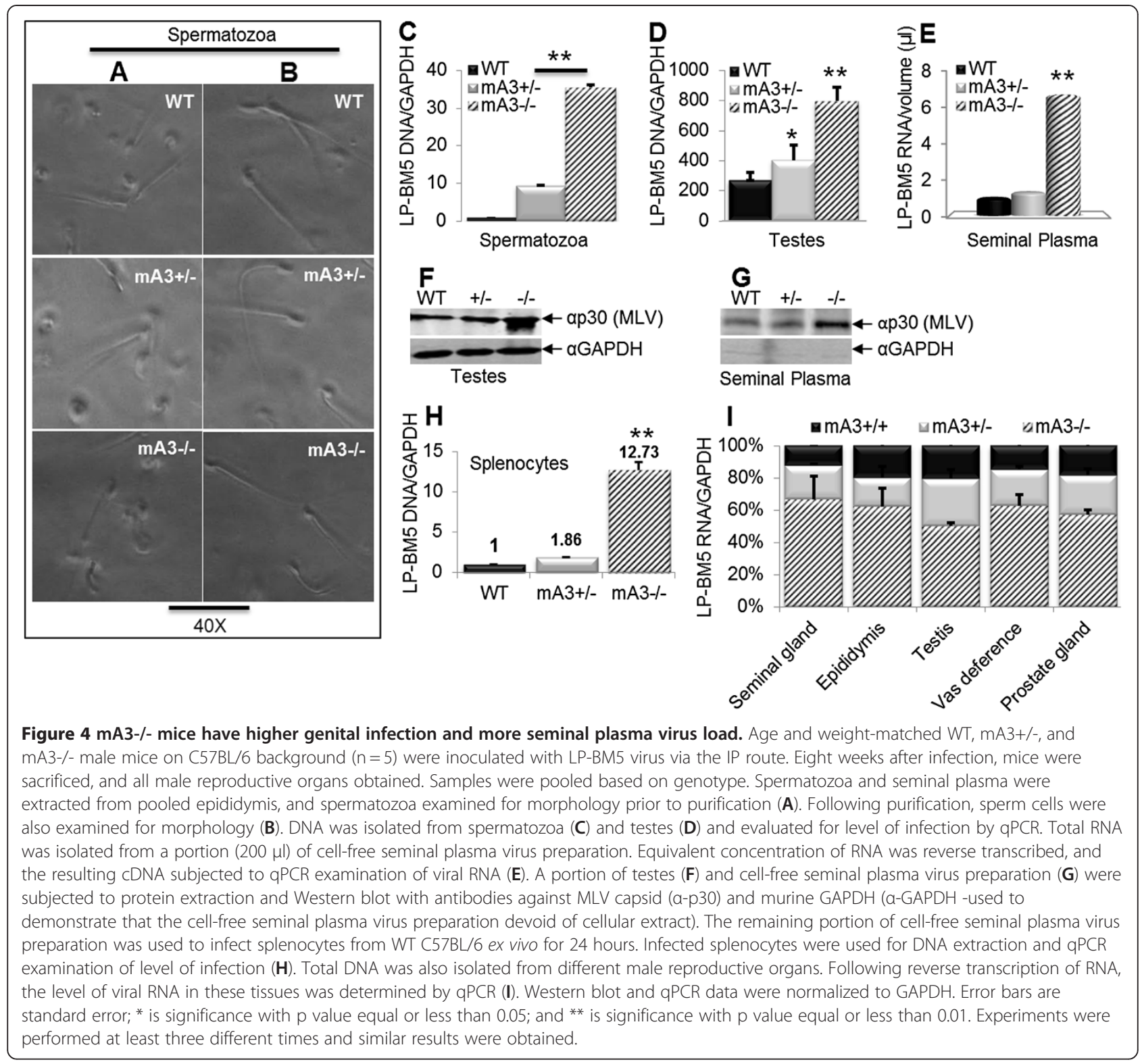

as evidenced by the presence of LP-BM5 DNA in spleen (Figures $5 \mathrm{C}$ to $5 \mathrm{E}$ ) and PBMCs (Figures $5 \mathrm{~F}$ to $5 \mathrm{H}$ ) of naïve females mated with infected mice. Rate of virus transmission was significantly higher in female mice mated with mA3-/- males irrespective of the female mice genotype (Figure $5 \mathrm{C}$ and $5 \mathrm{~F}$ ), followed by females mated with $\mathrm{mA3}+/-$ mice (Figure $5 \mathrm{D}$ and $5 \mathrm{G}$ ), then females mated with WT (Figure $5 \mathrm{E}$ and $5 \mathrm{H}$ ). Since rate of LP-BM5 replication is highest in $\mathrm{mA3}-/$ - mice (Figures $4 \mathrm{E}$ and $4 \mathrm{~F}$ ), we examined the impact of higher virus replication on sexual transmission. Examination of virus transmission from WT, $\mathrm{mA} 3+/-$, or mA3-/- infected male to WT females reveals that indeed, mA3-/- mice harbor significantly more virions compared to the $\mathrm{mA} 3+/-$, and WT counterparts in that order (Figure 5I and 5J). This result confirms that high rate of LP-BM5 replication in $\mathrm{mA3}-/$ - mice translates to high rate of sexual virus transmission.

Female mice sexually infected with LP-BM5 transmit the virus to their off-spring in APOBEC3-dependent manner mA3 mediates milk-borne transmission of MMTV from an infected female to her off-spring [47]. To validate the role of $\mathrm{mA} 3$ in sexual transmission of LP-BM5 virus, we examined rate of virus infection in the off-springs of female mice that were sexually infected by their male partners (Table 1). We found that off-springs of sexuallyinfected female mice of different genotypes are infected and that level of infection depends on the presence or absence of mA3 gene. Thus, mA3-/- off-springs (Figure 6A 


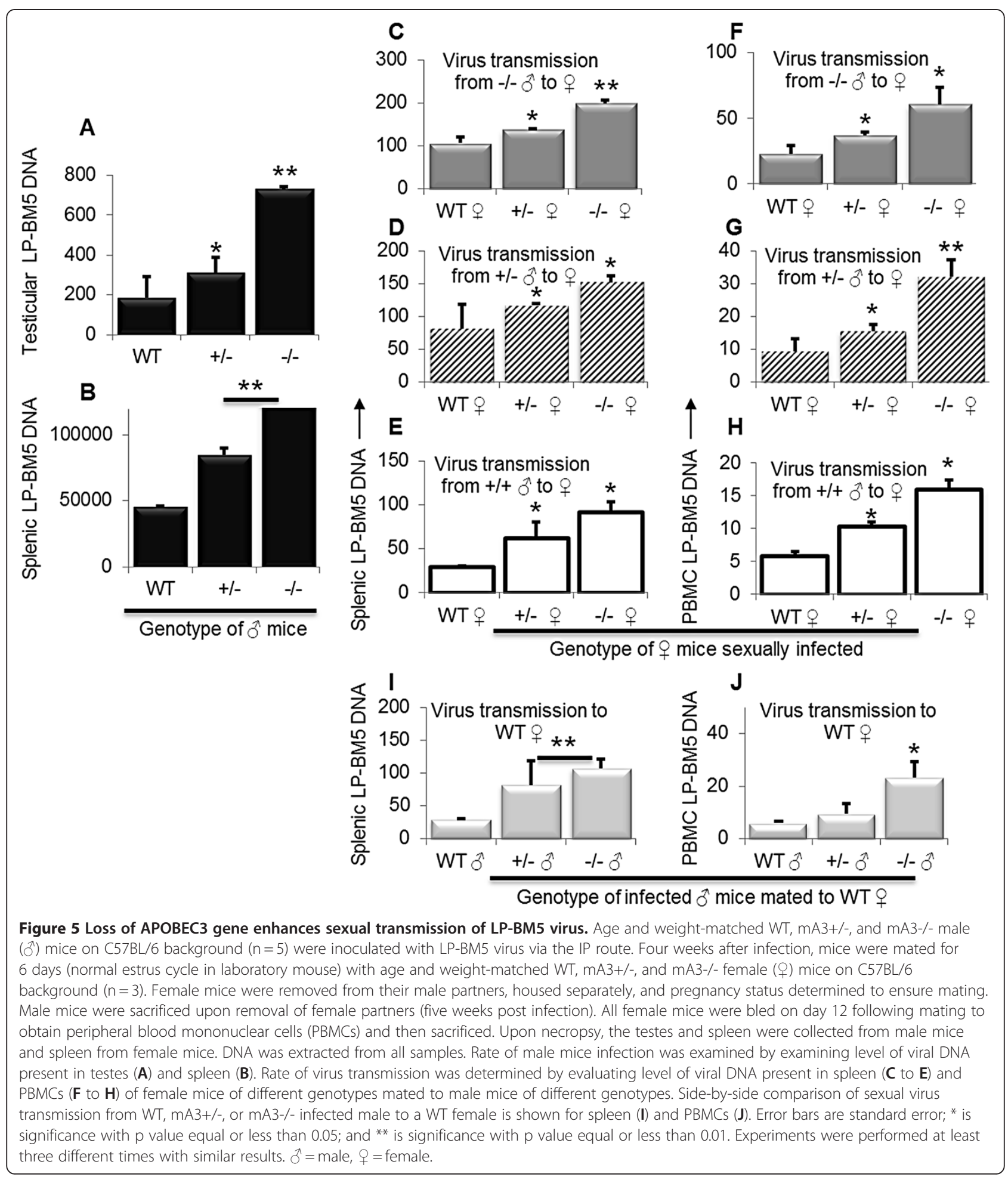

bar 2 and 6B lane 2) from $\mathrm{mA3}-/-$ male and $\mathrm{mA} 3+/-$ female (Figure $6 \mathrm{~B} \delta$ and $q$ ) show significantly higher levels of infection compared to their $\mathrm{mA} 3+/$ - litter mates (Figure 6A bars 1, 3, 4 and 6B lanes 1, 3, 4). Similar observations were made on 1) mA3-/- off-spring
(Figure 6D bar 3) from $\mathrm{mA3}+/$ - male and $\mathrm{mA3}-/$ - female (Figure $6 \mathrm{E} \delta$ and 9 ) compared to its $\mathrm{mA} 3+/$ - litter mates (Figure 6D bars 1, 2, 4, 5 and 6E lanes 1, 2, 4, 5); 2) $\mathrm{mA} 3+/$ - off-spring (Figure $6 \mathrm{G}$ bars 1,4 and Figure $6 \mathrm{H}$ lanes 1,4$)$ from $\mathrm{mA} 3+/-$ male and $\mathrm{mA} 3+/+$ female 
Table 1 mA3 genotype permutation for the generation of off-springs from parents of different genetic backgrounds

\begin{tabular}{|c|c|c|c|c|c|c|}
\hline \multirow{2}{*}{$\begin{array}{l}\text { Male }(\precsim) \\
\text { mA3 genotype }\end{array}$} & \multirow{2}{*}{$\begin{array}{l}\text { Female }(+) \\
\text { mA3 genotype }\end{array}$} & \multicolumn{5}{|c|}{ Off-spring $\mathrm{mA} 3$ genotype } \\
\hline & & 1 & 2 & 3 & 4 & 5 \\
\hline d 159 -/- & 우 $159 \mathrm{C}+/-$ & $+/-$ & $-/-$ & $+/-$ & $+/-$ & \\
\hline \multirow[t]{2}{*}{ o $160+/-$} & ㅇ $160 \mathrm{C}-/-$ & $+/-$ & $+/-$ & $-/-$ & $+/-$ & $+/-$ \\
\hline & q 160D WT & $+/-$ & WT & WT & $+/-$ & WT \\
\hline o $161 \mathrm{WT}$ & o $161 \mathrm{D}+/-$ & $+/-$ & $+/-$ & WT & WT & $+/-$ \\
\hline
\end{tabular}

(Figure $6 \mathrm{H} \hat{\sigma}$ and 9 ) compared to their $\mathrm{mA} 3+/+$ litter mates (Figure 6G bars 2, 3, 5 and Figure $6 \mathrm{H}$ lanes $2,3,5$ ); and 3) $\mathrm{mA} 3+/$ - off-spring (Figure $6 \mathrm{~J}$ bars 1, 2,
5 and Figure $6 \mathrm{~K}$ lanes 1, 2, 5) from WT male and $\mathrm{mA} 3+/-$ female (Figure $6 \mathrm{~K} \delta$ and $\phi$ ) compared to their WT litter mates (Figure 6J bars 3, 4 and

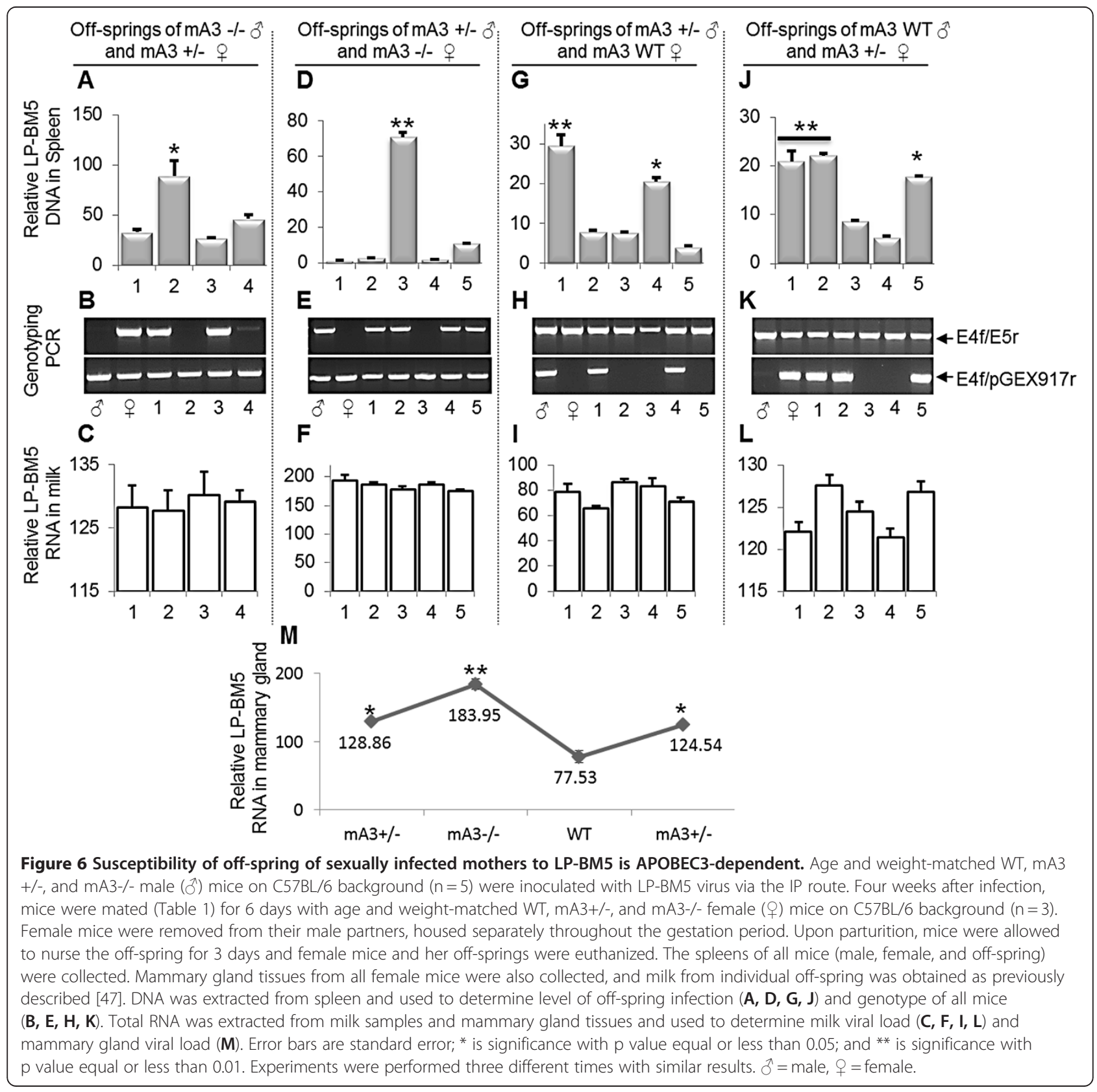


Figure $6 \mathrm{~K}$ lanes 3,4$)$. To confirm that these differences were off-spring-mA3 gene dependent, we examined the level of vRNA in milk consumed by each off-spring from the same sexually infected female. Our results indicate no differences in milk vRNA among offsprings from the same female (Figures 6C, 6F, 6I, 6L); however, differences abound in the amount of vRNA that females of different genotype harbor in their mammary gland tissues, and these differences correlate with the female mA3 genotype (Figures 6M). The fact that off-springs of sexually infected female mice were infected serve as a validation of sexual virus transmission from an infected male to the female counterpart. Variation in infection level observed between pups from different parents could stem from a number of factors, including genetic disposition of the pup with respect to different genes or related factors, amount of virus in mother's milk, rate of virus acquisition by individual pups - which could be influenced by the amount of milk consumed by the pup, as well as the amount of virus in mothers milk.

\section{Genital organ mA3 determines susceptibility to sexual transmission}

We have shown that $\mathrm{mA} 3$ is expressed in male genitalia (Figure $1 \mathrm{~A}$ and $1 \mathrm{~B}$ ) and that viral load in the genitalia organs is higher in mA3-/- mice (Figure 4F). Based on these data, we hypothesize that the higher rate of virus transmission from mA3-/- infected males to their naïve female partners is mediated by genitalia intrinsic mA3. Hence, we used adoptive transfer experiments to create mA3-/- mice that lack mA3 in the genital organs but express $\mathrm{mA} 3$ in their lymphocytes, and the control mice that are $\mathrm{mA} 3$ deficient in both genital organs and lymphocytes (Figure 7A). Results show that mA3-/- mice with WT stem cells show significantly lower splenocyte infection compared to the control mice with mA3-/stem cells (Figure 7B), indicating that mA3-/- splenocytes are more susceptible to infection. Comparison of genital organs (testes, epididymis, and seminal gland) infection from these mice reveals no differences in level of infection (Figures 7C to 7E). To determine whether mA3 intrinsically expressed in genital organs or lymphocytes is responsible for restricting sexual virus transmission, we mated naïve WT female mice with the above males (mA3-/- males with WT or mA3-/- cells). Contrary to our observation of male infection, splenocytes and mammary gland of female mice mated with and sexually infected by males that received WT or mA3-/cells have similar levels of infection (Figure 7F and 7G) indicating that the male genital environment controls virus transmission. Examination of the generation 1 (F1 - mA3+/-) off-springs of mA3-/- males and WT females at 4 and 13 weeks post parturition also reveal no differences in splenic viral load (Figure 7H and 7I). These genetic data suggest that genitalia-intrinsic mA3 is important and mediates restriction of sexual virus transmission.

\section{Discussion}

HIV is mostly propagated worldwide through sexual transmission. While a number of host factors have been identified to enhance sexual transmission of HIV [74], factors that limit sexual transmission of HIV have not been described. However, APOBEC3 as an anti-HIV factor that restricts infection of hematopoietic and nonhematopoietic cells $[47,50]$ could potentially play a role in sexual transmission. Recently, in vivo studies in mice show that APOBEC3 restricts MMTV infection of the lymphoid compartment, resulting in lower levels of virus infection in mammary tissue, accompanied by a decreased rate of milk-borne transmission of MMTV [47].

Here, we demonstrate a possible role for APOBEC3 in restricting a sexually transmitted virus infection. We show that mice with targeted deletion of the Apobec3 gene have higher rates of LP-BM5 infection in lymphoid and genital tissues, and that this results in enhanced rates of sexual transmission of LP-BM5 virus. It is known that LP-BM5 infects genital tissues [73] and causes severe immunodeficiency and splenomegaly [1822]. APOBEC3 is made in genital organs; interestingly, the absence of APOBEC3 in these organs, as in APOBEC3 knockout mice, altered infection of the genital organs. Higher level of infection in APOBEC3 knockout mice provides evidence that APOBEC3 mediates the susceptibility of the genitalia and gametes to virus infection. Additionally, the significantly higher vRNA in genital organs of APOBEC knockout mice (Figure 4I), as well as high levels of extracellular vRNA and protein in seminal plasma (Figure 4E and 4G) from APOBEC3 knock mice indicates that LP-BM5 is actively replicating more efficiently in the absence of APOBEC3. Our finding is in line with published reports [75,76] which showed the occurrence of active virus replication in semen of HIV-1 infected men. The alteration of virus infection in genital compartment in APOBEC3 knockout mice positively correlates with high level of viral RNA in seminal plasma, as well as increased infectivity of seminal plasma LP-BM5 virus compared to wild type mice. The demonstration that extracellular virions from seminal plasma obtained from APOBEC3 knockout mice are more infectious than that from control mice further confirms that loss of mA3 results in higher virus load (Figure $4 \mathrm{H}$ ). These results suggest that genital organintrinsic APOBEC3 expression serves to limit sexual transmission of LP-BM5, and perhaps other retroviruses. Indeed, we show that seminal fluid of APOBEC3 knock mice harbors more LP-BM5 virus compared to the wild type as visualized by Western blot (Figure 4G), but we 


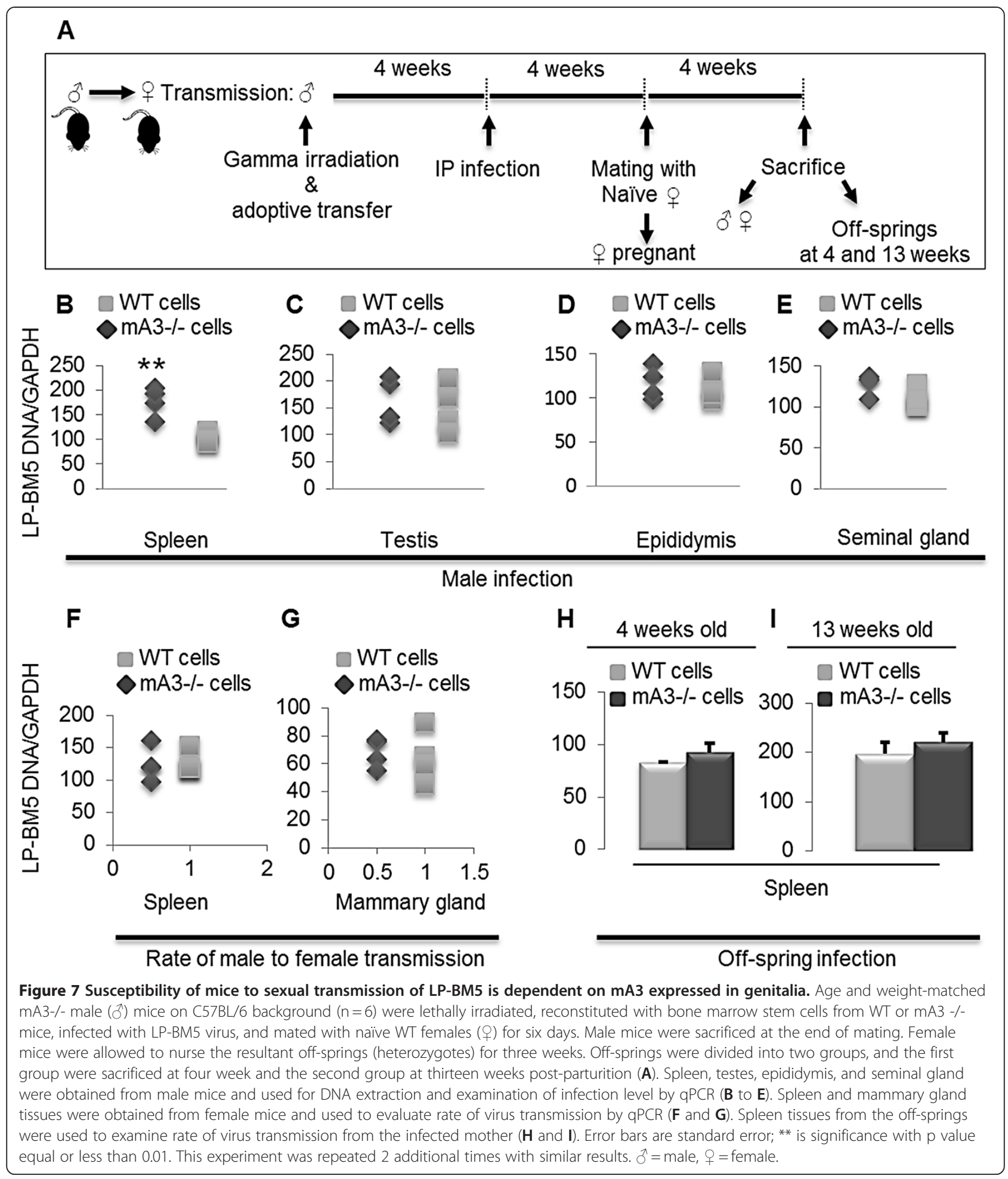

were unable to detect APOBEC3 due to perhaps the lack of good anti-mouse APOBEC3 antibodies or limited viral protein in samples from APOBEC3 sufficient mice. The detection of LP-BM5 proviral DNA in spermatozoa and testes support previous observations made with HIV-1 and herpesvirus type 8 [77-80].
Using genetic studies, we found that APOBEC3 mediates rate of sexual transmission of LP-BM5. The different permutations of genetic backgrounds used clearly show that the APOBEC3 gene is critical in determining the outcome of sexual transmission of LP-BM5 from one partner to the other, and from a sexually infected 
mother to her off-spring through nursing. Although loss of APOBEC3 enhanced rate of sexual transmission, we also observed that APOBEC3 deficient female mice were more highly infected compared to the heterozygote and wild type controls in that order. These genetic experiments show that APOBEC3 also plays a crucial role in mediating virus acquisition from an infected male and that the female genetic background contributes in defining the outcome of infection.

We also used adoptive transfer and in vivo genetic experiments to demonstrate a clear relationship between genital-intrinsic APOBEC3 and sexual transmission. Genital-intrinsic APOBEC3 mediates control of sexual transmission since higher levels of splenocyte infection observed in male mice that received APOBEC3 knockout cells did not translate to higher rate of female partner infection. This concept was further confirmed by similar level of infection observed in the off-springs of these mice irrespective of the male parent splenocyte APOBEC3 genotype.

While murine retroviruses (beta and gamma retroviruses) are sensitive to A3 antiviral activity, they have also successfully replicated in mice. It is not clear how these infectious viruses have evaded host restriction to achieve efficient replication, since they do not encode viral accessory proteins, such as the HIV-1 Vif protein that antagonizes some human A3 proteins. However, reports of alternative mechanisms used by murine retroviruses to evade restriction by A3 proteins exist. Indeed, MLV virions have been shown to exclude mA3 [81] as well as inactivate mA3 by viral protease [82], and xenotropic murine leukemia-virus related virus (XMRV) down-regulates hA3G in prostate cancer cells [83].

Sexual transmission of HIV-1 continues to be a problem worldwide, especially in developing countries, where access to condoms is restricted by cultural and socioeconomic situations. Previous studies have indicated that the use of HAART in the control of HIV transmission has mixed results since some HAART treated patients with suppressed plasma viral load continue to shed viral RNA in semen $[12,13]$.

\section{Conclusion}

As in immune cells and mammary epithelia cells, APOBEC3 is made in genital organs and gametes. Based on our data, we suggest that APOBEC3 expression in genital organs and gametes may have been retained as a means of inhibiting sexual transmission of viruses. In addition, APOBEC3 in genital organs could have important therapeutic implications for sexual transmission of viruses. For example, therapeutics could be developed that increase APOBEC3 level in genital organs, resulting in attenuated virions.

\section{Methods}

\section{Ethics statement}

Experiments involving the use of mice were performed in accordance to $\mathrm{NIH}$ guidelines, the Animal Welfare Act, and US federal law. Experiments were approved by the University of Iowa Animal Care and Use Committee (IACUC).

\section{Cells}

MEF and primary testicular cells were obtained from mA3-/-, mA3+/-, and WT mice on C57BL/6 background. SC1-G6 cells chronically infected with LP-BM5 (containing ecotropic, mink cell focus-forming and defective viruses) were obtained through the AIDS Research and Reference Reagent Program, Division of AIDS, NIAID, NIH from Dr. Herbert Morse and Dr. Janet Hartley $[15,19,23]$.

\section{Mice}

The mA3-knockout (mA3-/-) and matched controls $\mathrm{mA} 3+/-, \quad(\mathrm{mA} 3+/+, \mathrm{WT})$ mice have been previously described [45]. All mice were housed according to the policies of the Institutional Animal Care and Use Committee of the University of Iowa.

\section{Adoptive transfer}

Five age-matched (5 weeks old) male mice of each genotype were lethally irradiated with gamma rays. All radiation experiments were performed at the Radiation and Free Radical Research Core Facility of the University of Iowa. Mice were irradiated with a dose of 9 Gy (dose rate, $0.345 \mathrm{~Gy} / \mathrm{min}$ ) using a ${ }^{137} \mathrm{Cs}$ source (JL Shepherd, San Fernando, CA) as previously described [47]. Four hours after irradiation, mice were reconstituted with bone marrow stem cells from either mA3-/- or WT mice. Four weeks after reconstitution, the mice were inoculated with LP-BM5 virus. Prior to infection, peripheral blood lymphocytes from each mouse were subjected to FACs analysis with conjugated anti-mouse CD8, CD4, CD11c and B220, to test for uniform reconstitution.

\section{Virus propagation}

Cell-free LP-BM5 viral mixture was prepared from chronically infected SC-1 cells as previously described [84]. Culture supernatants were collected and centrifuged at $1500 \mathrm{rpm}$ for 10 minutes to clarify cellular debris. Clarified culture supernatants were filtered through a $0.45 \mu \mathrm{M}$ filter, layered on to $20 \%$ sucrose cushion and centrifuged at $7000 \mathrm{rpm}, 4{ }^{\circ} \mathrm{C}$ overnight. Virus pellet was resuspended in PBS at 10:1 ratio and aliquots of $100 \mu \mathrm{l}$ stored at $-80{ }^{\circ} \mathrm{C}$ until required for use. 


\section{Cell and mouse infection}

Infection of cells with cell culture or seminal plasma virus was done in triplicates in 96-well plate format. Briefly, primary testicular cells or splenocytes were plated at $\sim 100,000$ cells per well. Twenty four hours later, cells were incubated with $8 \mu \mathrm{g} / \mathrm{ml}$ of polybrene for 2 hours. Polybrene-containing medium was removed and replaced with $100 \mu \mathrm{l}$ of virus-containing medium or PBS for control. Cells were spinoculated at $1200 \mathrm{rpm}$ for 2 hours at room temperature. Following spinoculation, cells were incubated at $37{ }^{\circ} \mathrm{C}$ for 24 hours. DNA was extracted from cells for examination of viral load. Mice infections were done either subcutaneously (SubQ) on the hind footpad or intraperitoneally (IP). For footpad inoculation, $30 \mu \mathrm{l}$ of virus or PBS was injected into the footpad tissue and IP inoculation was performed with $200 \mu \mathrm{l}$ of virus or PBS. At the appropriate time depending on experiment, mice were sacrificed and relevant tissues obtained for downstream analysis.

\section{Genotyping mA3 -/- mice}

Mice genotypes were determined using two parallel PCRs as previously described [45]. Briefly, DNA was extracted and $50 \mathrm{ng}$ of genomic DNA and $25 \mathrm{pmol}$ of primers were used in a total volume of $25 \mu \mathrm{l}$ PCR reaction. PCR amplicons were separated on a $2 \%$ agarose gel.

\section{Nucleic acid isolation and real-time quantitative PCR}

Milk and seminal plasma viral loads were determined for BM5def as previously described [85]. Briefly, total RNA was isolated from seminal fluid $(200 \mu \mathrm{l})$ or milk $(50 \mu \mathrm{l})$ samples using Trizol RNA Reagent (AMRESCO). Isolated RNA was DNAsed and subjected to cDNA synthesis (Applied Biosystems, ABI) as previously described [86]. DNA was also isolated from different tissues using QIAGEN-QIAamp DNA Mini Kit following manufacturer's recommendation. Nucleic acid concentration and purity were measured spectrophotometrically at 260/ $280 \mathrm{~nm}$. DNA and cDNA were amplified with primers and probe specific to BM5def [87] and GAPDH using ABI 7500 FAST thermal cycler (ABI).

\section{Flow cytometry}

Approximately, $1 \times 10^{6}$ splenocytes were stained in PBS + $1 \%$ bovine serum albumin (Sigma-Aldrich) for $30 \mathrm{~min}$ utes on ice with APC-, FITC-, and PE-conjugated antibodies and the resulting immunofluorescence was analyzed by use of a FACSCalibur flow cytometer (BD) to detect the expression of murine CD69, B220, and CD4 (BD or eBioscience). Cellular frequency and fluorescence intensity were determined by Flowjo analysis software (TreeStar). APC-, FITC-, and PE-conjugated Ig isotypes of irrelevant specificity were used as control for each monoclonal antibody.

\section{Western blot}

Western blots of virus preparations and cell extracts were probed with anti-p30 (MLV capsid) and antiGAPDH. The species-appropriate IRDye secondary antibodies were used, followed by detection with the Odyssey Infrared Imaging System (LI-COR Biosciences).

\section{Virus purification from seminal plasma}

The seminal samples obtained from epididymis were processed immediately and pooled within genotype to provide sufficient seminal plasma volume and seminal cells. Pooled epididymal seminal samples were centrifuged for 15 minutes at $400 \mathrm{~g}$. The pellet was further purified to obtain pure sperm cells as discussed below. The supernatant was collected and filtered through a $0.45 \mu \mathrm{M}$ filter. Virions were purified from the supernatants by ultracentrifugation at $40,000 \mathrm{rpm}$ for $30 \mathrm{~min}$ utes. Viral pellet was resuspended in PBS and stored in $50 \mu \mathrm{l}$ aliquots at $-80{ }^{\circ} \mathrm{C}$ until required for use.

\section{Spermatozoa purification}

Pooled epididymal seminal samples were subjected to standard swim-up technique to purify sperm cells. Briefly, semen samples were centrifuged for $15 \mathrm{~min}$ at $400 \mathrm{~g}$. The pellets were resuspended in pre-warmed 2.5 ml Ham's F-10 culture medium (Sigma) supplemented with $10 \%$ human serum albumin. Cells were layered over equivalent volume of $80 \%$ Percoll and $40 \%$ Percoll and centrifuged for 15 minutes at $400 \mathrm{~g}$ as previously described [88]. The supernatant was discarded and the pellet was resuspended in Ham's F-10 culture medium and thereafter centrifuged for 15 minutes at $400 \mathrm{~g}$. The supernatant was removed and the pellet was overlaid with $2.5 \mathrm{ml}$ Ham's F-10 medium and incubated for $60 \mathrm{~min}$ in $5 \% \mathrm{CO}_{2}$ at $37{ }^{\circ} \mathrm{C}$ to allow spermatozoa to swim up from the pellet. A sterile Pasteur pipette was used to remove the supernatant containing actively motile sperms. A drop of the sample was examined under light microscope and images acquired with Nikon Eclipse $\mathrm{Ti}$ (Nikon Instruments). Purified cells were stored at $-80{ }^{\circ} \mathrm{C}$ until required.

\section{Statistical analysis}

The paired two-tailed Student's $t$ test was used for statistical analysis and a p value of 0.05 was considered significant. Error bars represent standard deviations.

\section{Abbreviations}

A3: APOBEC3; HIV: human immunodeficiency virus; MLV: murine leukemia viruses; mAIDS: murine acquired immunodeficiency syndrome.

\section{Competing interests}

The authors have no conflicting financial interests. 


\section{Authors' contributions}

CMO conceptualized and designed research, PHJ, HVM, CMO performed research, and analyzed data; $\mathrm{PHJ}, \mathrm{HVM}, \mathrm{CMO}$ wrote and read the paper. All authors reviewed the manuscript and approved the final version.

\section{Acknowledgments}

This research was supported by University of lowa Startup funds to CMO. $\mathrm{PHJ}$ was supported by Immunology T32 training grant to the University of lowa. The following reagent was obtained through the AIDS Research and Reference Reagent Program, Division of AIDS, NIAID, NIH: SC-1/MLV LP-BM5 from Dr. Herbert Morse and Dr. Janet Hartley. Radiation experiments were made possible by the Radiation and Free Radical Research Core Facility of the University of lowa and Holden Comprehensive Cancer Center Support Grant P30 CA086862. We would like to thank Bryson Okeoma for his analytical critique of this manuscript.

Received: 14 March 2012 Accepted: 16 May 2012

Published: 12 June 2012

\section{References}

1. Cameron DW, Simonsen JN, D'Costa LJ, Ronald AR, Maitha GM, Gakinya MN, Cheang M, Ndinya-Achola JO, Piot P, Brunham RC, et al: Female to male transmission of human immunodeficiency virus type 1: risk factors for seroconversion in men. Lancet 1989, 2:403-407.

2. Clumeck N, Taelman H, Hermans P, Piot P, Schoumacher M, De Wit S: A cluster of HIV infection among heterosexual people without apparent risk factors. N Engl J Med 1989, 321:1460-1462.

3. Royce RA, Sena A, Cates W Jr, Cohen MS: Sexual transmission of HIV. N Engl J Med 1997, 336:1072-1078.

4. Vernazza PL, Eron JJ, Fiscus SA, Cohen MS: Sexual transmission of HIV: infectiousness and prevention. AIDS 1999, 13:155-166.

5. Byrn RA, Zhang D, Eyre R, McGowan K, Kiessling AA: HIV-1 in semen: an isolated virus reservoir. Lancet 1997, 350:1141.

6. Delwart EL, Mullins Jl, Gupta P, Learn GH Jr, Holodniy M, Katzenstein D, Walker BD, Singh MK: Human immunodeficiency virus type 1 populations in blood and semen. J Virol 1998, 72:617-623.

7. Kroodsma KL, Kozal MJ, Hamed KA, Winters MA, Merigan TC: Detection of drug resistance mutations in the human immunodeficiency virus type 1 (HIV-1) pol gene: differences in semen and blood HIV-1 RNA and proviral DNA. J Infect Dis 1994, 170:1292-1295.

8. Taylor S, Boffito M, Vernazza PL: Antiretroviral therapy to reduce the sexual transmission of HIV. J HIV Ther 2003, 8:55-66.

9. Boden D, Hurley A, Zhang L, Cao Y, Guo Y, Jones E, Tsay J, Ip J, Farthing C, Limoli K, Parkin N, Markowitz M: HIV-1 drug resistance in newly infected individuals. JAMA 1999, 282:1135-1141.

10. Little SJ, Daar ES, D'Aquila RT, Keiser PH, Connick E, Whitcomb JM, Hellmann NS, Petropoulos CJ, Sutton L, Pitt JA, Rosenberg ES, Koup RA, Walker BD, Richman DD: Reduced antiretroviral drug susceptibility among patients with primary HIV infection. JAMA 1999, 282:1142-1149.

11. Hecht FM, Grant RM, Petropoulos CJ, Dillon B, Chesney MA, Tian H, Hellmann NS, Bandrapalli NI, Digilio L, Branson B, Kahn JO: Sexual transmission of an HIV-1 variant resistant to multiple reversetranscriptase and protease inhibitors. N Engl J Med 1998, 339:307-311.

12. Cu-Uvin S, DeLong AK, Venkatesh KK, Hogan JW, Ingersoll J, Kurpewski J, De Pasquale MP, D'Aquila R, Caliendo AM: Genital tract HIV-1 RNA shedding among women with below detectable plasma viral load. AIDS 2010, 24:2489-2497.

13. Cu-Uvin S, Caliendo AM: Genital tract HIV-1 RNA shedding among women with below detectable plasma viral load. AIDS 2011, 25:880-881.

14. Mosier DE: Animal models for retrovirus-induced immunodeficiency disease. Immunol Invest 1986, 15:233-261.

15. Chattopadhyay SK, Morse HC 3rd, Makino M, Ruscetti SK, Hartley JW: Defective virus is associated with induction of murine retrovirus-induced immunodeficiency syndrome. Proc Natl Acad Sci U S A 1989, 86:3862-3866.

16. Chattopadhyay SK, Sengupta DN, Fredrickson TN, Morse HC 3rd, Hartley JW: Characteristics and contributions of defective, ecotropic, and mink cell focus-inducing viruses involved in a retrovirus-induced immunodeficiency syndrome of mice. J Virol 1991, 65:4232-4241.

17. Jolicoeur P: Murine acquired immunodeficiency syndrome (MAIDS): an animal model to study the AIDS pathogenesis. FASEB J 1991, 5:2398-2405.
18. Morse HC 3rd, Yetter RA, Via CS, Hardy RR, Cerny A, Hayakawa K, Hugin AW, Miller MW, Holmes KL, Shearer GM: Functional and phenotypic alterations in T cell subsets during the course of MAIDS, a murine retrovirusinduced immunodeficiency syndrome. J Immunol 1989, 143:844-850.

19. Morse HC 3rd, Chattopadhyay SK, Makino M, Fredrickson TN, Hugin AW, Hartley JW: Retrovirus-induced immunodeficiency in the mouse: MAIDS as a model for AIDS. AIDS 1992, 6:607-621.

20. Yetter RA, Buller RM, Lee JS, Elkins KL, Mosier DE, Fredrickson TN, Morse $\mathrm{HC}$ 3rd: CD4+ T cells are required for development of a murine retrovirus-induced immunodeficiency syndrome (MAIDS). J Exp Med 1988, 168:623-635.

21. Cerny A, Hugin AW, Hardy RR, Hayakawa K, Zinkernagel RM, Makino M, Morse $\mathrm{HC}$ 3rd: B cells are required for induction of T cell abnormalities in a murine retrovirus-induced immunodeficiency syndrome. J Exp Med 1990, 171:315-320.

22. Cerny A, Hugin AW, Holmes $\mathrm{KL}$, Morse $\mathrm{HC}$ 3rd: CD4+ T cells in murine acquired immunodeficiency syndrome: evidence for an intrinsic defect in the proliferative response to soluble antigen. Eur J Immunol 1990, 20:1577-1581.

23. Hartley JW, Fredrickson TN, Yetter RA, Makino M, Morse HC 3rd: Retrovirusinduced murine acquired immunodeficiency syndrome: natural history of infection and differing susceptibility of inbred mouse strains. J Virol 1989, 63:1223-1231.

24. Pozsgay JM, Beilharz MW, Wines BD, Hess AD, Pitha PM: The MA (p15) and p12 regions of the gag gene are sufficient for the pathogenicity of the murine AIDS virus. J Virol 1993, 67:5989-5999.

25. Fraternale A, Casabianca A, Tonelli A, Vallanti G, Chiarantini L, Brandi G, Celeste AG, Magnani M: Inhibition of murine AIDS by alternate administration of azidothymidine and fludarabine monophosphate. J Acquir Immune Defic Syndr 2000, 23:209-220.

26. Fraternale A, Tonelli A, Casabianca A, Chiarantini L, Schiavano GF, Celeste AG, Magnani M: New treatment protocol including lympholytic and antiretroviral drugs to inhibit murine AIDS. J Acquir Immune Defic Syndr 2000, 23:107-113.

27. Mayhew CN, Sumpter R, Inayat M, Cibull M, Phillips JD, Elford HL, Gallicchio VS: Combination of inhibitors of lymphocyte activation (hydroxyurea, trimidox, and didox) and reverse transcriptase (didanosine) suppresses development of murine retrovirus-induced lymphoproliferative disease. Antiviral Res 2005, 65:13-22.

28. Beilharz MW, Sammels LM, Paun A, Shaw K, van Eeden P, Watson MW, Ashdown ML: Timed ablation of regulatory CD4+ T cells can prevent murine AIDS progression. J Immunol 2004, 172:4917-4925.

29. Dias AS, Bester MJ, Britz RF, Apostolides Z: Animal models used for the evaluation of antiretroviral therapies. Curr HIV Res 2006, 4:431-446.

30. Patterson BK, Landay A, Siegel JN, Flener Z, Pessis D, Chaviano A, Bailey RC: Susceptibility to human immunodeficiency virus-1 infection of human foreskin and cervical tissue grown in explant culture. Am J Pathol 2002, 161:867-873.

31. Johansson EL, Rudin A, Wassen L, Holmgren J: Distribution of lymphocytes and adhesion molecules in human cervix and vagina. Immunology 1999, 96:272-277

32. Olaitan A, Johnson MA, MacLean A, Poulter LW: The distribution of immunocompetent cells in the genital tract of HIV-positive women. AIDS 1996, 10:759-764.

33. Edwards JN, Morris HB: Langerhans' cells and lymphocyte subsets in the female genital tract. Br J Obstet Gynaecol 1985, 92:974-982.

34. Hladik F, Lentz G, Delpit E, McElroy A, McElrath MJ: Coexpression of CCR5 and IL-2 in human genital but not blood T cells: implications for the ontogeny of the CCR5+ Th1 phenotype. J Immunol 1999, 163:2306-2313.

35. Zhang L, He T, Talal A, Wang G, Frankel SS, Ho DD: In vivo distribution of the human immunodeficiency virus/simian immunodeficiency virus coreceptors: CXCR4, CCR3, and CCR5. J Virol 1998, 72:5035-5045.

36. Prakash M, Kapembwa MS, Gotch F, Patterson S: Higher levels of activation markers and chemokine receptors on T lymphocytes in the cervix than peripheral blood of normal healthy women. J Reprod Immunol 2001, 52:101-111.

37. Pichlmair A, Reis E, Sousa C: Innate recognition of viruses. Immunity 2007, 27:370-383.

38. Chiu YH, Macmillan JB, Chen ZJ: RNA polymerase III detects cytosolic DNA and induces type I interferons through the RIG-I pathway. Cell 2009, 138:576-591. 
39. Ablasser A, Bauernfeind F, Hartmann G, Latz E, Fitzgerald KA, Hornung V: RIG-I-dependent sensing of poly(dA:dT) through the induction of an RNA polymerase III-transcribed RNA intermediate. Nat Immunol 2009, 10:1065-1072.

40. Martinon F, Mayor A, Tschopp J: The inflammasomes: guardians of the body. Annu Rev Immunol 2009, 27:229-265.

41. Bhattacharya C, Aggarwal S, Kumar M, Ali A, Matin A: Mouse apolipoprotein B editing complex 3 (APOBEC3) is expressed in germ cells and interacts with dead-end (DND1). PLOS One 2008, 3:e2315.

42. Koning FA, Newman EN, Kim EY, Kunstman KJ, Wolinsky SM, Malim MH: Defining APOBEC3 expression patterns in human tissues and hematopoietic cell subsets. J Virol 2009, 83:9474-9485.

43. LaRue RS, Jonsson SR, Silverstein KA, Lajoie M, Bertrand D, El-Mabrouk N, Hotzel I, Andresdottir V, Smith TP, Harris RS: The artiodactyl APOBEC3 innate immune repertoire shows evidence for a multi-functional domain organization that existed in the ancestor of placental mammals. BMC Mol Biol 2008, 9:104

44. Su Al, Wiltshire T, Batalov S, Lapp H, Ching KA, Block D, Zhang J, Soden R, Hayakawa M, Kreiman G, Cooke MP, Walker JR, Hogenesch JB: A gene atlas of the mouse and human protein-encoding transcriptomes. Proc Natl Acad Sci U S A 2004, 101:6062-6067.

45. Okeoma CM, Lovsin N, Peterlin BM, Ross SR: APOBEC3 inhibits mouse mammary tumour virus replication in vivo. Nature 2007, 445:927-930.

46. Okeoma CM, Low A, Bailis W, Fan HY, Peterlin BM, Ross SR: Induction of APOBEC3 in vivo causes increased restriction of retrovirus infection. $J$ Virol 2009, 83:3486-3495.

47. Okeoma CM, Huegel AL, Lingappa J, Feldman MD, Ross SR: APOBEC3 proteins expressed in mammary epithelial cells are packaged into retroviruses and can restrict transmission of milk-borne virions. Cell Host Microbe 2010, 8:534-543.

48. Cullen BR: HIV-1 Vif: counteracting innate antiretroviral defenses. Mol Ther 2003, 8:525-527

49. Chiu YL, Greene WC: Multifaceted antiviral actions of APOBEC3 cytidine deaminases. Trends Immunol 2006, 27:291-297.

50. Malim MH: APOBEC proteins and intrinsic resistance to HIV-1 infection. Philos Trans R Soc Lond B Biol Sci 2009, 364:675-687.

51. Okeoma CM, Petersen J, Ross SR: Expression of murine APOBEC3 alleles in different mouse strains and their effect on mouse mammary tumor virus infection. J Virol 2009, 83:3029-3038.

52. Low A, Okeoma CM, Lovsin N, De Las Heras M, Taylor TH, Peterlin BM, Ross $\mathrm{SR}$, Fan $\mathrm{H}$ : Enhanced replication and pathogenesis of Moloney murine leukemia virus in mice defective in the murine APOBEC3 gene. Virology 2009, 385:455-463.

53. Bishop KN, Holmes RK, Sheehy AM, Davidson NO, Cho SJ, Malim MH: Cytidine deamination of retroviral DNA by diverse APOBEC proteins. Curr Biol 2004, 14:1392-1396.

54. Bishop KN, Holmes RK, Sheehy AM, Malim MH: APOBEC-mediated editing of viral RNA. Science 2004, 305:645.

55. Holmes RK, Koning FA, Bishop KN, Malim MH: APOBEC3F can inhibit the accumulation of HIV-1 reverse transcription products in the absence of hypermutation. Comparisons with APOBEC3G. J Biol Chem 2007, 282:2587-2595.

56. Aguiar RS, Lovsin N, Tanuri A, Peterlin BM: Vpr.A3A chimera inhibits HIV replication. J Biol Chem 2008, 283:2518-2525.

57. Sheehy AM, Gaddis NC, Choi JD, Malim MH: Isolation of a human gene that inhibits HIV-1 infection and is suppressed by the viral Vif protein Nature 2002, 418:646-650.

58. Conticello SG, Harris RS, Neuberger MS: The Vif protein of HIV triggers degradation of the human antiretroviral DNA deaminase APOBEC3G. Curr Biol 2003, 13:2009-2013.

59. Marin M, Rose KM, Kozak SL, Kabat D: HIV-1 Vif protein binds the editing enzyme APOBEC3G and induces its degradation. Nat Med 2003, 9:1398-1403.

60. Takeda E, Tsuji-Kawahara S, Sakamoto M, Langlois MA, Neuberger MS, Rada C, Miyazawa M: Mouse APOBEC3 restricts friend leukemia virus infection and pathogenesis in vivo. J Virol 2008, 82:10998-11008.

61. Langlois MA, Neuberger MS: Human APOBEC3G can restrict retroviral infection in avian cells and acts independently of both UNG and SMUG1. J Virol 2008, 82:4660-4664.

62. Huang M, Simard C, Jolicoeur P: Immunodeficiency and clonal growth of target cells induced by helper-free defective retrovirus. Science 1989, 246:1614-1617.
63. Simard $C$, Huang $M$, Jolicoeur $P$ : Murine AIDS is initiated in the lymph nodes draining the site of inoculation, and the infected $B$ cells influence $T$ cells located at distance, in noninfected organs. J Virol 1994, 68:1903-1912.

64. Huang M, Jolicoeur P: Myristylation of Pr60gag of the murine AIDSdefective virus is required to induce disease and notably for the expansion of its target cells. J Virol 1994, 68:5648-5655.

65. Huang M, Simard C, Kay DG, Jolicoeur P: The majority of cells infected with the defective murine AIDS virus belong to the B-cell lineage. J Virol 1991, 65:6562-6571.

66. Iwashiro M, Messer RJ, Peterson KE, Stromnes IM, Sugie T, Hasenkrug KJ: Immunosuppression by CD4+ regulatory $\mathrm{T}$ cells induced by chronic retroviral infection. Proc Natl Acad Sci U S A 2001, 98:9226-9230.

67. Okeoma CM, Shen M, Ross SR: A novel block to mouse mammary tumor virus infection of lymphocytes in B10.BR mice. J Virol 2008, 82:1314-1322

68. Pilcher CD, Shugars DC, Fiscus SA, Miller WC, Menezes P, Giner J, Dean B, Robertson K, Hart CE, Lennox JL, Eron JJ Jr, Hicks CB: HIV in body fluids during primary HIV infection: implications for pathogenesis, treatment and public health. AIDS 2001, 15:837-845

69. Pilcher CD, Eron JJ Jr, Vemazza PL, Battegay M, Harr T, Yerly S, Vom S, Perrin $\mathrm{L}$ : Sexual transmission during the incubation period of primary HIV infection. JAMA 2001, 286:1713-1714.

70. Whitney JB, Luedemann C, Hraber P, Rao SS, Mascola JR, Nabel GJ, Letvin $\mathrm{NL}$ : T-cell vaccination reduces simian immunodeficiency virus levels in semen. J Virol 2009, 83:10840-10843.

71. Quinn TC, Wawer MJ, Sewankambo N, Serwadda D, Li C, Wabwire-Mangen F, Meehan MO, Lutalo T, Gray RH: Viral load and heterosexual transmission of human immunodeficiency virus type 1. Rakai Project Study Group. N Engl J Med 2000, 342:921-929.

72. Gray RH, Wawer MJ, Brookmeyer R, Sewankambo NK, Serwadda D, Wabwire-Mangen F, Lutalo T, Li X, vanCott T, Quinn TC: Probability of HIV-1 transmission per coital act in monogamous, heterosexual, HIV-1-discordant couples in Rakai, Uganda. Lancet 2001, 357:1149-1153.

73. Okada Y, Abe E, Komuro K, Mizuochi T: Heterosexual transmission of a murine AIDS virus. J Virol 1998, 72:2541-2543.

74. Roan NR, Muller JA, Liu H, Chu S, Arnold F, Sturzel CM, Walther P, Dong M, Witkowska HE, Kirchhoff F, Munch J, Greene WC: Peptides released by physiological cleavage of semen coagulum proteins form amyloids that enhance HIV infection. Cell Host Microbe 2011, 10:541-550.

75. van Leeuwen E, de Vries JW, Jurriaans S, Verhoeve HR, Prins JM, Repping S, van der Veen F: Intra uterine insemination with processed sperm for HIV serodiscordant couples in whom the man is HIV positive. Ned Tijdschr Geneeskd 2005, 149:423-424.

76. Mermin JH, Holodniy M, Katzenstein DA, Merigan TC: Detection of human immunodeficiency virus DNA and RNA in semen by the polymerase chain reaction. J Infect Dis 1991, 164:769-772.

77. Nuovo GJ, Becker J, Simsir A, Margiotta M, Khalife G, Shevchuk M: HIV-1 nucleic acids localize to the spermatogonia and their progeny. A study by polymerase chain reaction in situ hybridization. Am J Pathol 1994, 144:1142-1148.

78. Bagasra O, Farzadegan H, Seshamma T, Oakes JW, Saah A, Pomerantz RJ: Detection of HIV-1 proviral DNA in sperm from HIV-1-infected men. AIDS 1994, 8:1669-1674

79. Bagasra O, Freund M, Weidmann J, Harley G: Interaction of human immunodeficiency virus with human sperm in vitro. J Acquir Immune Defic Syndr 1988, 1:431-435.

80. Bagasra O, Patel D, Bobroski L, Abbasi JA, Bagasra AU, Baidouri H, Harris T, El-Roeiy A, Lengvarszky Z, Farzadegan H, Wood C: Localization of human herpesvirus type 8 in human sperms by in situ PCR. J Mol Histol 2005, 36:401-412.

81. Doehle BP, Schafer A, Wiegand HL, Bogerd HP, Cullen BR: Differential sensitivity of murine leukemia virus to APOBEC3-mediated inhibition is governed by virion exclusion. J Virol 2005, 79:8201-8207.

82. Abudu A, Takaori-Kondo A, Izumi T, Shirakawa K, Kobayashi M, Sasada A, Fukunaga $\mathrm{K}$, Uchiyama $\mathrm{T}$ : Murine retrovirus escapes from murine APOBEC3 via two distinct novel mechanisms. Curr Biol 2006, 16:1565-1570

83. Dey A, Mantri CK, Pandhare-Dash J, Liu B, Pratap S, Dash C: Downregulation of APOBEC3G by xenotropic murine leukemia-virus related virus (XMRV) in prostate cancer cells. Virol J 2011, 8:531. 
84. Mosier DE, Yetter RA, Morse HC 3rd: Functional T lymphocytes are required for a murine retrovirus-induced immunodeficiency disease (MAIDS). J Exp Med 1987, 165:1737-1742.

85. Cook WJ, Green KA, Obar JJ, Green WR: Quantitative analysis of LP-BM5 murine leukemia retrovirus RNA using real-time RT-PCR. J Virol Methods 2003, 108:49-58.

86. Jones PH, Mehta HV, Maric M, Roller RJ, Okeoma CM: Bone marrow stromal cell antigen 2 (BST-2) restricts mouse mammary tumor virus (MMTV) replication in vivo. Retrovirology 2012, 9:10.

87. Giese NA, Giese T, Morse HC 3rd: Murine AIDS is an antigen-driven disease: requirements for major histocompatibility complex class II expression and CD4+ T cells. J Virol 1994, 68:5819-5824.

88. Lasheeb AS, King J, Ball JK, Curran R, Barratt CL, Afnan M, Pillay D: Semen characteristics in HIV-1 positive men and the effect of semen washing. Genitourin Med 1997, 73:303-305.

doi:10.1186/1742-4690-9-50

Cite this article as: Jones et al: A novel role for APOBEC3: Susceptibility to sexual transmission of murine acquired immunodeficiency virus (mAIDS) is aggravated in APOBEC3 deficient mice. Retrovirology 2012 9:50

\section{Submit your next manuscript to BioMed Central and take full advantage of:}

- Convenient online submission

- Thorough peer review

- No space constraints or color figure charges

- Immediate publication on acceptance

- Inclusion in PubMed, CAS, Scopus and Google Scholar

- Research which is freely available for redistribution 